12.

\title{
PRILOG ZA BIOGRAFIJU: POLITIČKA KARIJERA UROŠA DESNICE U VREMENU ISKUŠENJA (1919-1941)
}

\section{Dragan Bakić}

UDK: 32-05Desnica, U.

Izvorni znanstveni članak

Sažetak: Ovaj esej pokušava da rekonstruiše političku karijeru Uroša Desnice u vremenu između dva svetska rata. Izdanak veoma poznate porodice, Desnica je bio jedna od najistaknutijih političkih figura među Srbima u severnoj Dalmaciji. Posebna pažnja posvećena je njegovim pogledima na srpsko-hrvatske odnose i jugoslovensku ideju, ali je predmet analize i njegov angažman u okviru Narodne radikalne stranke i Jugoslovenske nacionalne stranke u vreme šestojanuarske diktature i kasnije, kao i obavljanje državnih funkcija, prvo kao potpredsednik pokrajinske dalmatinske vlade, a zatim kao narodni poslanik i senator. Desnica je bio veliki srpski patriota, ali je iskreno verovao i da su Srbi, Hrvati i Slovenci jedan narod i da je Kraljevina SHS prirodno i srećno otelotvorenje jugoslovenske ideje. Tokom dvadesetih godina je bio veliki protivnik Hrvatske seljačke stranke Stjepana Radića, čak i u vreme kada je ona bila koalicioni partner u vladi njegovim radikalima, jer ju je smatrao srbofobskom i antidržavnom, ali nikada nije skliznuo u šovinizam. Prihvatio je i podržavao lični režim kralja Aleksandra iz dubokog uverenja da je on bio neminivnost u uslovima teške krize i da je koncept integralnog jugoslovenstva ispravan i spasonosan za zemlju. Iskrenost svog jugoslovenskog uverenja Uroš Desnica je dokazao time što mu je ostao veran i nakon smrti kralja Aleksandra, kada je došlo do oživljavanja „plemenskih stranaka“, pa i posle formiranja Banovine Hrvatske.

Ključne reči: Uroš Desnica, severna Dalmacija, Srbi, Hrvati, Jugoslavija, Narodna radikalna stranka

njiževnik Vladan Desnica je za svoga oca Uroša kazao da je bio „čovek velike kulture, ne samo opšte nego i literarne specijalno, i vrlo istančanog ukusa, odličan stilista". ${ }^{\text {Sta- }}$ riji Desnica (1874-1941) je takođe bio istaknuta politička figura i publicista svoga doba, ali je njegova aktivnost do sada skoro potpuno izmakla pažnji istraživača. Jedini radovi koji bacaju svetlost na njegovu društvenu i političku delatnost pojavili su se 2014. godine 
iz pera Draga Roksandića. ${ }^{2}$ Uzimajući u obzir ne samo pređašnje odsustvo bilo kakvog zaokruženog priloga, već i popriličnu prazninu i konfuziju u pogledu i najelementarnijih podataka iz njegove biografije, pa $\mathrm{i}$ - po svoj prilici - namerna prećutkivanja i iskrivljavanja pojedinih epizoda iz njegovog života, izazvana ideološkim potrebama istoriografije u socijalističkoj Jugoslaviji, ovaj pionirski poduhvat je zapravo tek otvorio istraživanje života i dela Uroša Desnice, kao i njegovog vremenskog i prostornog konteksta. ${ }^{3}$ Ova studija je stoga zamišljena kao dalji prilog skidanju mrene sa Desničine političke aktivnosti utemeljen na arhivskom materijalu, publikovanim izvorima i istorijskoj literaturi. U prvom redu, predmet pažnje je slabo poznata Desničina karijera tokom čitavog međuratnog perioda, sa posebnim osvrtom na njegove stavove o srpsko-hrvatskim odnosima, sve do njegove smrti neposredno nakon okupacije Kraljevine Jugoslavije u Aprilskom ratu. Izvesne činjenice vezane za ovu temu mogu da se utvrde sa sigurnošću, neke druge ostaju i dalje nerazjašnjene na osnovu do sada poznatih izvora, ali se ipak može ponuditi i svojevrsna slika celine njegove javne delatnosti u razmatranom periodu.

Izdanak izuzetno poznate i ugledne srpske porodice iz Ravnih kotara, čije poreklo, po ženskoj liniji, datira od uskočkih serdara iz porodice Mitrović Janković, koji su se u mletačkoj službi isticali u borbi protiv Turaka tokom druge polovine XVII veka pa su čak i ovekovečeni u epskoj pesničkoj tradiciji, ${ }^{4}$ Uroš Desnica je i sam, u praskozorje stvaranja Kraljevine Srba, Hrvata i Slovenaca na kraju Prvog svetskog rata, bio prominentna srpska figura iz severne Dalmacije. Obrazovan na Bečkom univerzitetu, gde je stekao i doktorat iz prava, on se još 1905, kada je imao 31 godinu, istakao kao pristalica novog kursa srpskohrvatske saradnje i, kao takav, učestvovao sa svojim ocem Vladimirom, načelnikom opštine Obrovac, u donošenju Zadarske rezolucije. U pogledu svoga stava prema aktivnostima Srpske stranke na Primorju u vreme izbora za cislajtanijsko Carevinsko veće, Desnica se legitimiše kao pristalica nadkonfesionalne, etno-lingvističke koncepcije definisanja srpske nacije nasuprot versko-ekskluzivnog pristupa nametnutog od sveštenstva Srpske crkve prema kome se pripadnost srpskoj naciji izjednačavala sa pripadnošću pravoslavnoj veri. To je, na primer, isključivalo iz nacionalnog korpusa dubrovačke Srbe-katolike na čelu sa samim Antunom Pugliesijem, predsednikom pomenute stranke.

Dešavanja tokom Prvog svetskog rata, pre svega ubrzani razvoj jugoslovenskog pitanja, ostavili su snažan utisak na Desnicu i on sam, pomalo egzaltirano, što mu inače nije bilo svojstveno, priznaje sa punom iskrenošću evoluciju koju su njegova lična shvatanja pretrpela. „Odrastao u doba mržnje“, Desnica se prisećao u svom članku situacije koja je bila tipična za sve ljude njegove generacije, Srbe i Hrvate podjednako, „zadojen duhom naših

2 Drago Roksandić, „Zatvaranje kruga. Dr Uroš Desnica (Obrovac, 28. VIII 1874 - Split, 13. VII 1941)“, Spomenica dr Danice Milić (ur. Bojana Miljković-Katić), Beograd 2014., 295-313; „Dr. Uroš Desnica 1918. - 1921.: životopisne nedoumice na raskrižju epoha", Spalatumque dedit ortum: zbornik povodom desete godišnjice Odsjeka za povijest Filozofskog fakulteta u Splitu (ur. Ivan Basić i Marko Rimac), Split 2014., 499-511.

3 Za diskusiju o kontroverzama u pogledu biografija Uroša i drugih članova njegove porodice vidi: Vladan Jovanović, „Članovi porodice Desnica u jugoslovenskim enciklopedijama i leksikonima“, Dijalog povijesničara - istoričara, knj. 9 (ur. Hans-Georg Fleck i Igor Graovac), Zagreb 2005., 243-257.

4 Milorad SAvić (ur.), Baština dvora Jankovića, Beograd 2006.

5 Za Desničinu karijeru pre Prvog svetskog rata vidi: D. Roksandić, „Zatvaranje kruga“, 299-301. 
novinskih polemika osamdesetih i devedesetih godina prošloga vijeka, ja sam mrzio Hrvatstvo, kao što se samo dušmanin mrziti može (...) ja sam odbacivao svako duševno srodstvo s njim.“6 U junu 1918. situacija se izmenila iz korena: „Danas su moja djeca u zabuni pred pitanjem, jesu li Srbi ili Hrvati, danas su stihovi Smailage i Putnika njihovo umno blago, danas nad njihovim stolom, megju slikama Dositija i Vuka, visi lik biskupa Strosmajera!“7 Po Desnici, rat je bio taj katalizator koji je okončao proces otrežnjenja i spoznaje „i tako je mogao da sazori blagosloveni plod našeg bratstva i jedinstva“ pa on ide tako daleko da čak blagosilja rat, jer je stvorio jugoslovenski narod, što smatra neotuđivom tekovinom bez obzira na to kako će se rat završiti. ${ }^{8}$ Međutim, kako se lako oduševio tako je Desnica brzo i potpuno potonuo u očajanje gledajući otpore jugoslovenskom jedinstvu koji su se iznova manifestovali u samom tom narodu sve dok nisu i „u zagrebačkoj sabornici odjeknule opet one strune o srpstvu i hrvatstvu, za koje sam držao, da su na vijeke pokopane“. . Ali kada je krah Austro-Ugarske postao vidljiv i ostvarenje jugoslovenske ideje se našlo nadohvat ruke, Desnica je povratio bodrost duha, kao i veru u političku mudrost i budućnost svoga naroda, pa je pokajnički izjavio da „pada na koljena pred svojim narodom i moli ga, da mu prosti (...) najteži grijeh u danima narodnog sloma, grijeh malodušnosti “. ${ }^{10}$ Početkom novembra 1918. godine, neposredno pred kraj rata, u haosu koji je pratio raspad AustroUgarske, dolazi do emancipacije od austrijske vlasti i formiranja Zemaljske vlade za Dalmaciju, koju su sačinjavali Ivo Krstelj, Josip Smodlaka i Vjekoslav Škarica, kao i njihovi zamenici Uroš Desnica, Prvislav Grisogono i Jerko Machiedo. Desnica je imenovan i za poverenika za pravosuđe. ${ }^{11} \mathrm{U}$ prvim godinama nakon rata veliki deo Dalmacije se našao pod okupacijom Italije. Ona je išla za tim da obezbedi sebi tekovine koje su joj obećane od strane sila Antante tajnim Londonskim paktom iz aprila 1915. Desničin politički stav, kao i organizovanje otpora protiv okupacione vlasti, najviše se ogledao u njegovoj aktivnoj ulozi u prikupljanju potpisa za „Apel naroda sjeverne Dalmacije“ u opštinama Knin, Drniš, Kistanje i Obrovac kao vidu demonstracije i pritiska na Parisku mirovnu konferenciju da se ovo područje pripoji novoformiranoj Kraljevini Srba, Hrvata i Slovenaca. Zbog toga je

$6 \quad$ Muzej Srpske pravoslavne crkve, Beograd (dalje: Muzej SPC), Fundus dvora Jankovića, Zbirka Dr Uroša Desnice (1874-1941) [dalje Zbirka Uroša Desnice], fascikle 4-5, fasc. 5, omot 6 (1918. godina), „Srpski glas“, Novo doba (Split), br. 4, 12. jun 1918. Građa iz citiranog fonda, koja se našla u Muzeju SPC usled ratnih okolnosti tokom 1990ih godina, nije dostupna istraživačima redovnim putem i još uvek se očekuje da se reši pitanje njenog definitivnog statusa, odnosno trajnog pohranjivanja. Kako je nesporni vlasnik građe porodica Desnica, meni je omogućeno da konsultujem njen sadržaj zahvaljujući saglasnosti datoj od strane g. dr. sc. Uroša Desnice (u njegovo i u ime njegovih sestara). Stoga dugujem neizmernu zahvalnost g. Desnici, kao i ljubaznom i predusretljivom upravniku Muzeja SPC, g. Vladimiru Radovanoviću, koji je ispoštovao preporuku g. Desnice i učinio sve u njegovoj moći da mi se, nakon dobijanja saglasnosti Sinoda SPC, omogući istraživanje ove građe. Bez toga, ovaj rad bi svakako bio mnogo siromašniji sadržajem.

7 Isto.

8 Isto.

9 Muzej SPC, Zbirka Uroša Desnice, fascikle 4-5, fasc. 5, omot 6 (1918. godina), „Snaga bez očiju“, Novo doba (Split), br. 45, 24. jul 1918.

10 Muzej SPC, Zbirka Uroša Desnice, fascikle 4-5, fasc. 5, omot 6 (1918. godina), „Snaga s očima“, Novo doba (Split), br. 128, 15. oktobar 1918.

11 Dušan Plenča, Kninska ratna vremena 1850-1946: Knin, Drnǐ̌, Bukovica, Ravni Kotari, Zagreb 1986., 72; Sofija Božıć, Srbi u Hrvatskoj 1918-1929., Beograd 2008., 654, 687.

12 D. Roksandić, „Zatvaranje kruga“, 304-306 i „Dr. Uroš Desnica 1918. -1921.“, 504-506 . 
sa bratom Boškom interniran u martu 1919. u Italiju, odakle se vratio kući krajem te godine. Po povratku u Zadar pokrenuo je Naš list, čiji je bio vlasnik u saradnji sa odgovornim urednikom Krunom Penovićem, ali ovo glasilo se nije dugo održalo. ${ }^{12}$

Ponovo je preuzeo svoje dužnosti u Zemaljskoj vladi Dalmacije, sada upravnom organu Kraljevine Srba, Hrvata i Slovenaca, što mu je bilo olakšano, a možda i jedino moguće, s obzirom na činjenicu da se, napustivši svoju advokatsku kancelariju u italijanskom Zadru, preselio sa porodicom u Split 1920. godine. U okviru reorganizacije, ukazom od 2. septembra iste godine, Desnica je postao poverenik za unutrašnje poslove i zamenik predsednika vlade. ${ }^{13}$ Delatnost Desnice u ovom telu obavijena je velom neznanja u nedostatku odgovarajućih arhivskih istraživanja, ukoliko su ona uopće moguća s obzirom na stanje građe. Tek mali uvid pruža nam njegov telegram upućen vladi u Beogradu. U njemu se interesuje da li je ostavka Iva Krstelja na mesto predsednika dalmatinske vlade usvojena, što je imalo naročitu važnost za njega, jer mu je Krstelj „poverio (...) upravu redovnom zapisničkom predajom“. Preuzevši poslove predsednika vlade, Desnica je uveo u dužnost, na osnovu već izdatog naređenja, poverenika za prosvetu prof. Vinka Lozovinu. On naročito podvlači teške prilike u kojima je kriza stvorena ostavkom zatekla pokrajinsku vladu:

Dok nadzor nad komunističkim pokretom zauzima svu pažnju Predsedništva Pokrajinske Vlade (...) počeli su da se pojavljuju i u okupiranoj zoni pa i u našem području izvesni znakovi nervoznosti i nestrpljenja, koji izazivlju razne neugodne incidente sa okupatornim vlastima i sa komandom talijanske ratne lagje „Puglia“ koja je još uvek usidrena u splitskoj luci. ${ }^{14}$

Desnica se pribojavao da bi pomenuti incidenti mogli da poprime ozbiljne razmere kako je to strahovalo i Ministarstvo unutrašnjih poslova u Beogradu, a uporedo je jedva uspevao da izađe na kraj sa nedoglednim tekućim poslovima bez potrebne administrativne podrške:

Kad se tomu još nadodadu pripreme za okupaciju teritorije, koja će nam po Rapalskom ugovoru [iz 1920.] biti ustupljena, te silni rad koji je s tim skopčan i gotovo nesavladive poteškoće u nalaženju potrebnog i zgodnog personala za razne upravne grane i u razmeštanju vlasti i činovništva, koje treba da iz Zadra seli, pa onda ostali redovni poslovi unutrašnjeg resora, može se lako doći do uverenja, kako sve to postavlja na jednog čoveka takove zahteve, kojima on i pored najbolje volje i najintensivnijeg rada ne može da udovolji. ${ }^{15}$

Nije poznato šta je centralna vlada odgovorila Desnici ovom prilikom, ali je, na osnovu njegovog vlastitog tvrđenja, on vršio dužnost namesnika Dalmacije, u skladu sa novom reorganizacijom vlasti koja je predviđala namesnike i za Hrvatsku, Sloveniju i Bosnu, sve do oktobra 1921. kada je Stevan Metličić konačno preuzeo tu funkciju. Desnica je u međuvremenu dao ostavku na svoje mesto u pokrajinskoj vladi, koja je i usvojena 21. jula 1921 godine. ${ }^{16}$ Prethodno je imao tu satisfakciju da se, u ime Zemaljske vlade kojom je upravljao,

13 Citirani document Uroša Desnice u: D. Roksandić, „Dr. Uroš Desnica 1918. - 1921.“, 502.

14 Arhiv Jugoslavije, Beograd (dalje: AJ), Ministarski savet Kraljevine Jugoslavije, 138-20-81, Potpredsednik pokrajinske vlade za Dalmaciju Uroš Desnica Predsedništvu Ministarskog saveta, poverljivo, 13. januar 1921., Br. Pres: $325 / 21$.

15 Isto.

16 D. Roksandić, „Dr. Uroš Desnica 1918. - 1921.“, 502. Za svoje zasluge tokom službovanja u dalmatinskoj pokrajinskoj vladi Desnica je odlikovan Kraljevskim ordenom Svetoga Save drugog reda 18. novembra 1921. godine. Povelja o odlikovanju nalazi se u Muzej SPC, Zbirka Uroša Desnice, fascikle 1-3, fasc. 1, omot 1. 
našao u pratnji vojske i žandarmerije koja je 4. aprila 1921. godine pošla iz Splita u Knin, što je označilo i konačan kraj italijanske okupacije čitavog područja Dalmacije, koje je pripalo Kraljevini SHS. ${ }^{17}$ Tačni razlozi koji su ponukali Desnicu da podnese ostavku nisu poznati: da li je, osim činjenice na koju je nešto ranije sam ukazivao, da je teret dužnosti u postojećim uslovima bio pretežak za svakog pojedinca, postojalo i nezadovoljstvo druge vrste? Sa okončanjem italijanske okupacije, najveća muka pokrajinske vlade ipak je bila uklonjena, ali to očigledno nije uticalo na njegovu odluku da se povuče sa odgovornog mesta.

Desničin dalji angažman u političkom životu novoformirane jugoslovenske države neraskidivo je vezan sa njegovom partijskom pripadnošću. Tokom dvadesetih godina prošlog veka Desnica je bio istaknuti član Narodne radikalne stranke pod vodstvom Nikole Pašića, koju je doživljavao kao jedinu istinski državotvornu partiju naslonjenu na svetle četrdesetogodišnje tradicije svoga trajanja i oprobanu ruku svoga već legendarnog vođe. Radikali su postigli odličan rezultat na izborima održanim 18. marta 1923. godine u izbornom okrugu Šibenik i oblast Zadarskog suda - osvojena su tri poslanička mandata koja su pripala Desnici, Ljubomiru Jovanoviću, jednom od najistaknutijih prvaka iz beogradske centrale, i dr Nikoli-Niku Novakoviću iz Knina, a poslanici iz severne Dalmacije postali su i dvojica Hrvata, dr Mate Drinković i Mate Goreta. ${ }^{18} \mathrm{Na}$ krilima ovog velikog izbornog uspeha, radikali izgrađuju i učvršćuju svoju stranačku organizaciju na ovom prostoru. Formiraju se dva nova sreska odbora Radikalne stranke na čelu sa novoizabranim poslanicima: u Kninu 22. aprila pod predsedništvom Nike Novakovića i u Benkovcu 6. maja pod vođstvom Desnice. ${ }^{19}$ Iako apsolutno lojalan svojoj Radikalnoj stranci i njenom lideru Pašiću, Desnica odbija nameštenje u državnoj službi u Dalmaciji, valjda iz povređene sujete zbog ponude koju nije smatrao adekvatnom, ali isto tako odbija i ponudu samoga Pašića iz avgusta 1923. da preuzme portfelj Ministarstva za socijalnu politiku u njegovoj vladi iz razloga koji nam ostaju nepoznati. ${ }^{20}$ Ovo nezadovoljstvo dalje eskalira i dostiže vrhunac 3. oktobra iste godine kada on - „razočaran“, kako je to kasnije naveo njegov prijatelj - podnosi ostavku na svoje mesto u Narodnoj skupštini, nakon nešto više od pola godine trajanja svog poslaničkog mandata. Njegov mandat preuzeo je advokat Nikola Subotić. ${ }^{21}$

Čini se da je Desničino nezadovoljstvo i odbijanje da neposredno učestvuje u političkom životu, bilo kao funkcioner pokrajinske uprave dok je ona postojala, bilo kao ministar ili narodni poslanik, stajalo u vezi sa njegovom razočaranošću tokom kojim su se razvijale unutrašnje prilike u zemlji, čije manifestacije je on pratio na lokalnom nivou i u svakodnevnom životu sa tihim nezadovoljstvom. U tekstu koji nije štampan, posvećenom likvidaciji pokrajinske uprave u Dalmaciji na čelu sa njegovim naslednikom Stevanom Metličićem,

17 S. Božıć, Srbi u Hrvatskoj, 28.

$18 \mathrm{Za}$ analizu izbornih rezultata vidi Sofija Božıć, „Između demokrata i radikala: produbljivanje političkih podela među Srbima u Hrvatskoj i parlamentarni izbori 1923“, Istorija 20. veka, 25/2007., br. 2, 46-47.

19 S. Božıć, Srbi u Hrvatskoj, 481.

20 D. Roksandić, „Zatvaranje kruga“, 306-307.

21 Stenografske beleške Narodne skupštine Kraljevine Srba, Hrvata i Slovenaca, Pregled o radu Narodne Skupštine Kraljevine Srba, Hrvata i Slovenaca za skupštinsku periodu od 16. aprila 1923. do 10. novembra 1924., Beograd 1928., 33-34, 302; Muzej SPC, Zbirka Uroša Desnice, fascikle 6-7; 9-10, fasc. 9, omot 1, pismo Vladimira Simića Urošu Desnici, 28. jun 1928. 
čime je ta pokrajina prestala da postoji kao posebna upravna jedinica, a njen poslednji namesnik u milosti otpušten u penziju, Desničin komentar odiše prikrivenom ironijom i rezigniranom pomirljivošću: on govori o „tri medene godine“ Metličićeve vlasti koje su, ne donevši nikakav naročiti napredak, ali ni posebnih problema za stanovništvo i državnu vlast, ostale zapamćene kao „posljednja stranica dalmatinske istorije, ispisana (...) sivom bojom“, a samom Metličiću donele su „srećan završetak svoje činovničke karijere“. ${ }^{22}$ Desnica je bio razočaran i merom svog uticaja i uticaja dalmatinskih radikala na centralne vlasti kada se radilo o pitanjima od značaja za njihov kraj. Stalni neuspesi da se državna vlast privoli da učini više, žalio se, „su nam ubili kredit i uticaj u Dalmaciji“ pa zato nije bilo čudno da se „u našim širim provincijskim krugovima stvorilo uvjerenje o našoj nemoći i o svojoj bespomoćnosti i što smo mi osjetili udes kosovske djevojke, pod čijom su se rukom sušili zeleni borovi“. ${ }^{23}$ Pored toga, Desnica i ostali dalmatinski radikali su bili potišteni usled razmirica u partijskom vrhu u Beogradu, naročito u vreme raskola između Pašića i Ljube Jovanovića, drugog čoveka u stranci i poslanika iz Primorja, što je neminovno slabilo i njihov položaj, pa je to, uz ostale pomenute razloge, doprinosilo izvesnoj Desničinoj mrzovoljnoj i samonametnutoj pasivizaciji i izolaciji koja je njegovom bliskom stranačkom kolegi delovala kao „depresija“. ${ }^{24}$

Od najranijeg formativnog perioda postojanja Kraljevine SHS Desnica se našao preokupiran, sasvim prirodno za jednog Dalmatinca, sa problemom srpsko-hrvatskih odnosa i saniranja unutrašnjih trzavica u zajedničkoj državi. Već sredinom 1922. godine učestvuje u anketi sprovedenoj među uglednim javnim ličnostima na stranicama Srpskog književnog glasnika o uzocima i načinu prevazilaženja srpsko-hrvatskih suprotnosti. Za njega nema nikakve sumnje da krivica za podvojenost leži na hrvatskoj strani: nasuprot odsustvu plemenskog ekskluzivizma kod Srba, koje je očito u neinsistiranju na srpskom imenu u nazivu stranaka, stoji faktičko stanje plemenske podvojenosti Hrvata koja je ,jedna svesna, volitivna i javno propovedana politička tendencija“ očigledna u programima njihovih stranaka i za čije je uklanjanje potrebno lečiti „bolesnu psihu“. ${ }^{25}$ Sami Hrvati, posebno oni iz Dalmacije, kao naročito rodoljubivi i svesni, čime se očigledno aludiralo na njihovo jugoslovenstvo, su ponajviše pozvani da pristupe tom lečenju koje bi trebalo da bude potpomognuto sa srpske strane popuštanjem i predusretljivošću koji jedino ne bi smeli da ugroze državno jedinstvo. Ako bi svi pokušaji ostali bezuspešni, Desnica upozorava, milion srpskih žrtava u ratu mora bar da obezbedi jedinstvo srpskog plemena.

Tokom 1924. godine pojavljuju se prvi znaci da će doći do smirivanja sukoba sa Hrvatskom republikanskom seljačkom strankom, pre svega nakon najave njenog predsednika Stjepana Radića da će prekinuti pasivnu rezistenciju i uzeti učešća u radu Skupštine. Desnica se tim povodom oglašava na stranicama lista Država, koji je izdavao Okružni odbor

\footnotetext{
22 Muzej SPC, Zbirka Uroša Desnice, fascikle 4-5, fasc. 5 (1924. godina), „Stevo Metličić“.

23 Muzej SPC, Zbirka Uroša Desnice, fascikle 4-5, fasc. 5 (1926. godina), „Da se razumijemo“, Država (Split), br. 216, 29. maj 1926.

24 Muzej SPC, Zbirka Uroša Desnice, fascikle 6-7; 9-10, fasc. 9, omot 1, dva nedatirana pisma Josipa Jablanovića Urošu Desnici [1926. godina].

25 Srpski književni glasnik, knj. 6, 16. maj 1922., 118-119.
} 
Narodne radikalne stranke u Splitu, u kome će i narednih godina iznositi svoje političke stavove. On je vidno rezervisan prema Radićevoj izjavi i smatra da ona može nešto da znači samo ukoliko bude propraćena prekidom sa prošlošću, odnosno odricanjem od svog političkog programa, prihvatanjem narodnog i državnog jedinstva, odbacivanjem republikanstva i iskrenom privrženošću Kralju. Pribojava se, međutim, da je Radićeva namera da uđe u Skupštinu „u ulozi trojanskog konja“. ${ }^{26}$ Od tog vremena Desnica vodi kontinuiranu i žestoku borbu sa Radićem i njegovom strankom koja je, na momente, prožeta dubokim pesimizmom u pogledu eventualnog srpsko-hrvatskog sporazuma. Taj pesimizam se bazira, pored ostalih neumitnih i neprijatnih činjenica svakodnevnog partijskog života, na njegovom viđenju dubinskih psihološko-socijalnih raspoloženja hrvatskog naroda:

Mi moramo zato da bez straha, i ako ne bez stida, pogledamo stvarnosti u oči i da muški kažemo onu istinu, koju svi u sebi osjećamo i koju se svak boji da izreče: hrvatsko pleme, u svojoj ogromnoj većini, mrzi Srbe i Srbiju, mrzi Vlahe, Rkaće, Race onom mračnom, srednjovjekovnom mržnjom, koja je to fanatičnija što je bezrazložnija. Njegova želja sporazuma prividna je a neiskren je njegov vapaj za slogom. (...) Ono hoće da kida veze u koje je ušlo krfskim paktom i decembarskom adresom, ono hoće da posije so na temelje ove države u koje je srpsko pleme uzidalo kosti svojih sinova. ${ }^{27}$

Krajem iste godine vraća se na ovu temu i, predstavljajući svojevrsan portret Radića kome on odriče svaku ljudsku i političku vrednost, dokazuje da je njegova popularnost rezultat specifičnog stanja „hrvatskog javnog mišljenja, koje bol prošlosti i razočaranje sadašnjosti združuje u zemaljskom obožavanju ovog lažnog idola“, pa dodaje kako „Radićeva mržnja može Srbima samo da služi na čast“ i predviđa da se sporazum može postići „samo preko Radića i protiv Radića“. ${ }^{28}$

Uoči samog sporazuma između Pašića i Radića i ulaska HSS-a u vladu, nakon što je ta stranka priznala Vidovdanski ustav i monarhiju Karađorđevića (i zato izbacila odrednicu republikanska iz svog imena), Desnica strahuje da će cenu tog sporazuma platiti Srbi u Dalmaciji pa diskretno apeluje na radikalsko vođstvo u Beogradu da ne žrtvuje tu provinciju. ${ }^{29} \mathrm{Nje}$ gov stav nije bio usamljen među vodećim dalmatinskim radikalima; naprotiv, on je izražavao opšte mišljenje i strahovanje koji su kasnije, u trenucima najvećeg nezadovoljstva, dovodili do otvorenog protesta upućenog „beogradskim vlastodršcima partije“.30 Kada je sporazum postao realnost u leto 1925., Desnica i dalje ne menja svoj stav niti veruje u trajnost takvog aranžmana. Na konferenciji u Splitu 23. avgusta 1926. on se otvoreno založio za raskidanje sporazuma između radikala i HSS zbog anti-srpskog i anti-jugoslovenskog držanja potonje stranke.

26 Muzej SPC, Zbirka Uroša Desnice, fascikle 4-5, fasc. 5 (1924. godina), „Pašić i Radić“, Država (Split), br. 1, 16. april 1924.

27 Muzej SPC, Zbirka Uroša Desnice, fascikle 4-5, fasc. 5 (1924. godina), „Zakon mržnje“, Država (Split), br. 39, 30. avgust 1924.

28 Muzej SPC, Zbirka Uroša Desnice, fascikle 4-5, fasc. 5 (1924. godina), „Junak našeg doba“, Istina: nedeljni politički časopis, 1/1924., br. 10-11.

29 Muzej SPC, Zbirka Uroša Desnice, fascikle 4-5, fasc. 5 (1924. godina), „Sporazum i provincija“, Država (Split), br. 118,10 jun 1925.

30 Muzej SPC, Zbirka Uroša Desnice, fascikle 6-7; 9-10, fasc. 9, omot 1, pismo Josipa Jablanovića Urošu Desnici, 18. jul [1925.]; nedatirano pismo Jablanovića Desnici [citirano]; pismo Jablanovića Desnici, 20. maj 1926. 


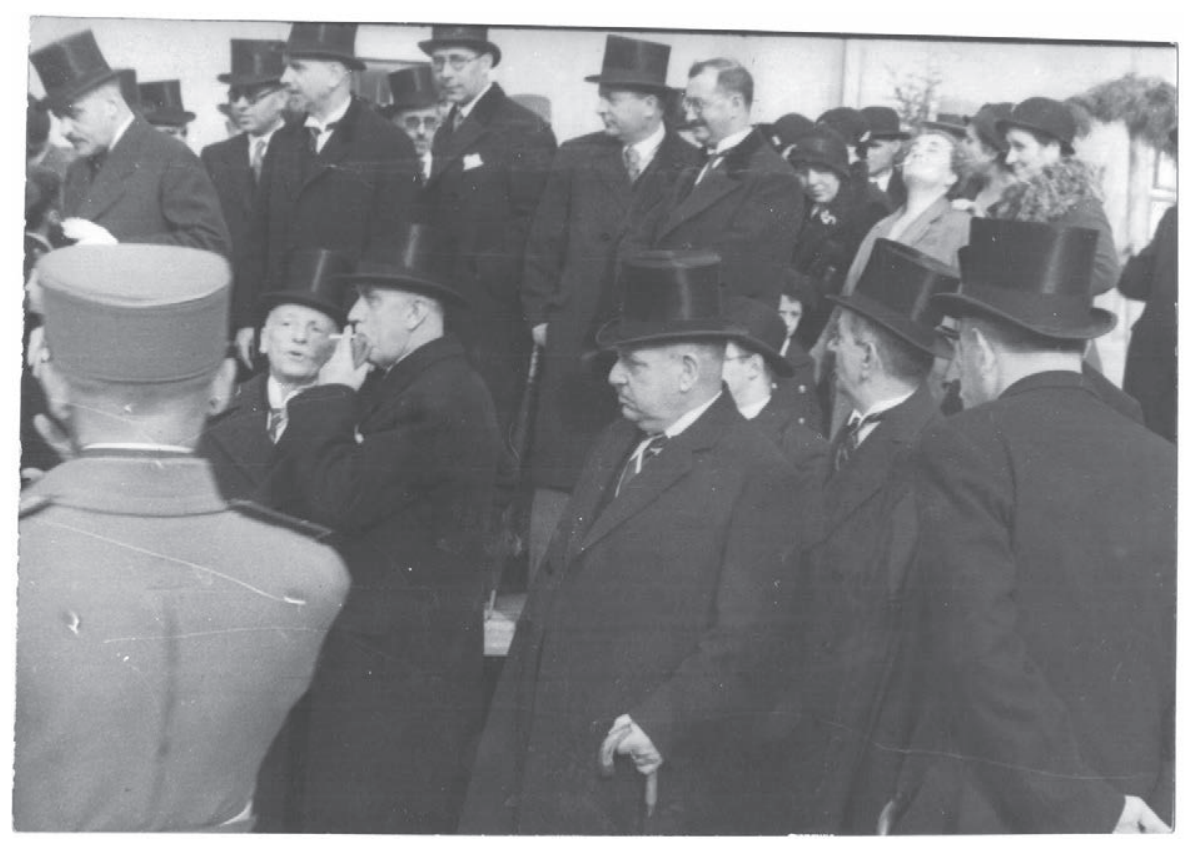

Sl. 1. Uroš Desnica na nepoznatom skupu

Naročito je istakao lokalne probleme u Dalmaciji, koja je u potpunosti prepuštena Radiću, kao koalicionom partneru, što je dovelo do toga da su nacionalno orijentisani ljudi, pod čime se podrazumevaju oni jugoslovenski nastrojeni, ugroženi od pristalica bivšeg austrijskog režima. ${ }^{31}$ Partijsku pristrasnost Pavla Radića pri formiranju komisije za rešavanje agrarnih odnosa u Dalmaciji tumačio je kao jedan od „onih skrovitih računa kojima je podan prvi znak zahtjevom za smenu nekih viših činovnika u Dalmaciji i koji nam, kao kroz maglu, naslućuju bračnu nevjeru našeg političkog druga“ ${ }^{32}$ Potom se ponovo vraća na žalostan položaj dalmatinskih radikala koji su ne samo nebitni stranačkoj centrali već predstavljaju i jedan teret u njenim političkim kombinacijama sa HSS. ${ }^{33}$ Desničine verbalne razmene sa Radićem lično su brutalne i on mu, u odgovoru na napade hrvatskog lidera izrečene na jednom zboru, javno baca uvrede u lice - „lažac i klevetnik, austrijski izmećar i izdajica“ su izrazi kojima opisuje šefa HSS - i poziva ga da ga tuži sudu gde će on imati obavezu da dokaže svoje navode. ${ }^{34} \mathrm{U}$ trenutku kada se Radić okrenuo protiv Pašića i optužio ga za korupciju, Desnica nije odoleo da ne podseti da su on i „skromni provinciski listić“ dalmatinskih radikala odavno opominjali na to šta će proisteći „iz sađenja tikava sa Stjepanom Radićem“. 35

\footnotetext{
31 S. Božıć, Srbi u Hrvatskoj, 524, fusnota 147.

32 Muzej SPC, Zbirka Uroša Desnice, fascikle 4-5, fasc. 5, „Dalmatinski radikali protiv radićevaca“ [preuzet tekst iz „Čist račun, duga ljubav“, Država (Split), br. 150, 29. septembar 1925.], Riječ (Zagreb), br. 227, 3. oktobra 1925.

33 Muzej SPC, Zbirka Uroša Desnice, fascikle 4-5, fasc. 5 (1926. godina), „Da se razumijemo“, Država (Split), br. 216, 29. maj 1926.

34 Muzej SPC, Zbirka Uroša Desnice, fascikle 4-5, fasc. 5 (1926. godina), „Pismo Dr. U. Desnice Stjepanu Radiću“, Obrovac, 7. jula 1926, Novo doba (Split), br. 156, 10. jul 1926.

35 Čedomir Vıšnjıć, Srbi u Hrvatskoj 1918-1941: anotirana bibliografija, Zagreb 2000., 153; odlomak iz „Sveti Jovan pred sudom", Država (Split), br. 265, 4. decembar 1926.
} 
Neposredno nakon objavljivanja ovog teksta u Državi, čime je Desnica dao oduška svojoj ličnoj satisfakciji, neprikosnoveni vođa radikala Pašić je preminuo i stranka se ubrzo našla u velikoj krizi. Započeta frakcijska podela među radikalima pokazaće se hronična i neizlečiva u odsustvu snažnog autoriteta koji bi zamenio Pašićev, u kojoj će jedna grupa obično činiti okosnicu vlade, a druga stajati u opoziciji. Desnica, koji će tokom tridesetih godina i sam biti predmet ove vrste frakcijske borbe, pozvao je svoje stranačke kolege da se održe na okupu i da se svaka žrtva podnese u cilju spasa države, a „da se ne pitamo jesmo li za vladu ili glavni odbor “. ${ }^{36}$ Gledano u retrospektivi, njegove reči su bile proročke.

Nakon ubistva dvojice poslanika HSS-a u Skupštini u junu 1928. i teškog ranjavanja Radića, koji će nešto kasnije umreti, zemlja se našla u teškoj krizi. Desnica promišlja o njenim uzrocima i ovoga puta, za razliku od svojih ranijih istupa, nalazi da oni podjednako leže na obe strane: hrvatska strana nije dala svoj doprinos formiranju nove države, a srpska se nije u duhovnom pogledu otrgla iz svojih predratnih granica i vladala je čitavom novom, velikom i kulturno heterogenom zemljom iz takvih uskih okvira. ${ }^{37}$ Desnica prihvata uvođenje šestojanuarske diktature kralja Aleksandra, mada ne bez žala što je i njegova Radikalna stranka raspuštena kao i sve ostale - veruje da su principi na kojima je ona utemeljena ispravni i da će na kraju odneti pobedu. Sa druge strane, on pristaje uz novo stanje sa uverenjem da „prestanak ustavnosti i parlamentarizma u onom degenerisanom obliku, koji je kod nas bio prevladao, kao plod prenaglog prelaska iz političke i nacionalne podregjenosti u carstvo neograničene slobode (...) morao je da sobom donese i prestanak partijskog društvenog uregjenja“. 38

Najočiglednija manifestacija Desničinog pristajanja uz lični režim kralja Aleksandra je njegov izbor, na osnovu oktroisanog ustava iz septembra 1931. godine, za senatora iz Primorske banovine, zajedno sa Nikolom Prekom i Ivom Majstrovićem na dan 3. januara sledeće godine. ${ }^{39}$ Čini se da je ulazak u Senat proizašao iz razočarenja prethodnog perioda: Radikalna stranka kojoj je ostao veran uprkos svom neslaganju sa njenom politikom osula se nakon Pašićevog nestanka sa scene, a ideologija integralnog jugoslovenstva ponudila je alternativni put za prevazilaženje hrvatskog pitanja - mada promašen, kako će to vreme pokazati - i to u skladu sa njegovim dubokim uverenjem o ispravnosti dogme o narodnom jedinstvu. Desnica nije bio naročito aktivan senator. Najčešće nije bio prisutan prilikom glasanja, a u onim mnogo ređim situacijama kada je sedeo u sali, podržavao je zakonske predloge vlade. Bio je član Finansijskog odbora Senata koji je preporučio za usvajanje predloge Zakona o kovanju srebrnog novca, Zakona o izmenama i dopunama Zakona o porezu na poslovni promet i Zakona o izmenama i dopunama Zakona o državnoj trošarini u avgustu 1932. godine, važnim u vreme velike privredne depresije koja je vladala u Jugosla-

36 Muzej SPC, Zbirka Uroša Desnice, fascikle 6-7; 9-10, fasc. 6, omoti 1-7, „Propast ili obnova?“, Država (Split), br. 310, 23. jul 1927.

37 Muzej SPC, Zbirka Uroša Desnice, fascikla 8, „Na Vidovdan 1928.“, Država (Split), br. 395, 27. juna 1928.

38 Muzej SPC, Zbirka Uroša Desnice, fascikle 6-7; 9-10, fasc. 6, omot 2 (1928. godina), „Našim Prijateljima“ i „Saopštenje izdavalaca 'Države'“, Država (Split), br. 444, 2. februar 1929.

39 Stenografske beleške Senata Kraljevine Jugoslavije, Prvi prethodni sastanak Senata, br. 1, sastanak održan 11. januara 1932., Beograd 1932., 2, 8. 
viji i čitavom svetu u to vreme..$^{40}$ Zabeleženo je samo jedno njegovo obraćanje sa senatske govornice. Ovaj govor je bio potpuno posvećen problemima njegove severne Dalmacije, za šta su kao povod poslužili slučajevi ubacivanja oružja i paklenih mašina iz Italije i istrage koja je usledila, praćene izvesnim prekoračenjima službenih ovlašćenja od strane žandarmerije. Otuda je Desnica izneo još jedanput svoje poglede na međunacionalne odnose u svom rodnom kraju:

Vi treba da znate, gospodo, da smo mi u pogledu državne vjernosti već od 1918 godine imali mnogo zala, imali mnogo protivnosti i mnogo dušmana u samoj našoj provinciji da savladamo i da ih priljubimo za ovu državu i da mi u tom nismo potpuno uspeli. Tako daleko smo došli ne zato što bi jedan žandarm digao ruku na jednog građanina ili sto žandarma na sto građana, nego zato što je takva psihološka osnova jednog dela stanovništva u Dalmaciji koje ja neću da delim na Srbe i Hrvate, jer smo mi svi složni da smo svi jednako Jugosloveni, ali kad mora da se napravi jedno diferenciranje (...) na pravoslavne i katolike. ${ }^{41}$

Desnica odbija prigovore opozicije da je za takvo stanje odgovorna politika vlade, jer ona nije progonila građane zato što su Hrvati ili katolici. Zato se on pita „okle bi se porodila kod toga naroda želja za slobodnom i nezavisnom Hrvatskom“ kada se za 120 godina pod austrijskom vlašću, od Kampoformijskog do Senžermenskog mirovnog ugovora, ta parola nikada nije čula u narodu, pa ni kod inteligencije. On navodi ekonomske i administrativne koristi koje su severnodalmatinski srezovi imali u novoj jugoslovenskoj državi. Doduše, Desnica nalazi da ima i krivice do vlasti, ali ona se sastoji u tome što su „demagogijom stvorili u njemu [narodu] pretstavu o njegovoj svemoći“. Kao dokaz svoje teze, on navodi sledeće: „Ovaj narod prima badava zemlju, on biva razdužen, on se hrani i dobija hrane kad je gladan, on se leči - jer treba znati šta je sve učinjeno u pogledu suzbijanja malarije i kolika je ta antimalarična kampanja za koju su se potrošili milioni (...) i sve mu to još nije dosta." Drugu veliku grešku državnih vlasti Desnica vidi u pauperizaciji buržoazije do koje je došlo usled sprovođenja agrarne reforme na način koji je on smatrao pogubnim i zavedenim levičarskim teorijama: „Upropašćen je (...) onaj konzervativni, onaj državotvorni, svesni stalež (...) koji je nosio državne tradicije, i na koga se država mogla osloniti, jer je bio kod naroda uticajan." Nakon što je izneo svoje viđenje problema, Desnica daje preporuku kako da se oni prevaziđu: pored ekonomskog i privrednog podizanja, važno je „podizati nacionalizam i svest za državu, treba širiti zadrugarstvo, treba osnivati sokolska društva i pored okružnica“, kao i „ublažavati versku međusobnu mržnju“. U pogledu ovog poslednjeg, on smatra da je ujedinjenje katoličke i pravoslavne crkve utopija i da je pravi put razvijanje tolerancije između dve konfesije i dodaje da „tu trpeljivost kod katoličke strane ne nalazimo" za šta dokaz nalazi u držanju krčkog biskupa Josipa Srebrnića. ${ }^{42}$ Čitav govor prikazuje senatora Desnicu kao odgovornog političara koji se potpuno pridržava zvanične linije šestojanuarskog režima: oštre reči koje je ranije upućivao na adresu pokojnog Radića

\footnotetext{
40 Stenografske beleške senata Kraljevine Jugoslavije, knj. II, od XVIII do XL redounog sastanka od 22 marta do 19 oktobra 1932, Beograd 1932., 279-284, 290-293.

41 Stenografske beleške senata Kraljevine Jugoslavije, XXXIII redovni sastanak, držan 29. mart 1933., Beograd 1933., $178-182$.

42 Isto.
} 
i njegove stranke zamenjene su mnogo umerenijim stavom koji je utemeljen u prihvatanju zvanične koncepcije integralnog jugoslovenstva. Pored toga, Desnica je bio i jedan od 18 pravnih eksperata - ne inicijalnih, već je to postao naknadno - članova Vrhovnog zakonodavnog saveta (postojao je od 4. februara 1929. do 7. decembra 1931), savetodavnog organa predsednika Ministarskog saveta, koji je delovao pri Ministarstvu pravde sa zadatkom da pregleda i ocenjuje projekte zakona, uredbi i pravilnika sa zakonskom snagom. ${ }^{43}$

Sa formiranjem vlade Milana Stojadinovića u junu 1935. otvara se jedno novo poglavlje u unutrašnjoj politici Kraljevine Jugoslavije. Delujući u saglasnosti sa regentom, knezom Pavlom, Stojadinović diskretno, ali ipak sasvim vidljivo, odstupa od zvanične ideologije narodnog jedinstva. Već u samoj programskoj deklaraciji svoje vlade, ali i u drugim svojim nastupima, Stojadinović govori o Srbima, Hrvatima i Slovencima, a ne o Jugoslovenima. Daje i nagoveštaje, sasvim neodređene doduše, da je spreman na davanje širokih lokalnih samouprava, što je ukazivalo na njegovu spremnost da traži rešenje za zahteve Hrvata. Ovaj otklon Stojadinovića od politike pokojnog kralja Aleksandra nije promakao pristalicama Jugoslovenske nacionalne stranke, koji su bili zatočnici Kraljeve baštine, pre svega principa nacionalnog i državnog jedinstva. Četiri meseca nakon što je Stojadinović postao premijer velika grupa senatora, pripadnika JNS, potpisala je interpelaciju senatora Koste Timotijevića, predsednika poslaničkog kluba te stranke, od 11. novembra u kojoj je novi politički kurs vlade izložen oštroj kritici. Među potpisnicima interpelacije našao se i Desnica. Time se on svrstao uz optužbu da se vladina politika „vodi i sprovodi u praksi protivu osnovnih načela zdrave istinske jugoslovenske misli “ ${ }^{44} \mathrm{U}$ tekstu interpelacije navodi se da vladina politika liberalizacije političkog života, koja je podrazumevala, između ostalog, da se dopusti javno manifestovanje hrvatskih nacionalnih simbola i osećanja („puštanje ventila“ kako se to govorilo), nije donela priželjkivano stišavanje strasti u zemlji, već pad autoriteta državnih organa i bezmalo anarhiju u pojedinim krajevima zemlje. Tvrdi se takođe da se u narodnim masama stvara utisak da je Kraljev akt od 6. januara, kao i sve što on simbolizuje, reakcionaran i uzrok teškog stanja u zemlji koji vlada svojim merama pokušava da prevaziđe. Vraćanje političkih sloboda, u praksi ako ne i u zakonodavnoj sferi, i obnavljanje starih „plemenskih“" partija doveli su, suprotno od očekivanog, do zaoštravanja plemenskih sukoba i erupcije nasilja uperenog protiv svih svetinja države i nacije, pa i omogućili ,jedan nezapamćen terorizam protiv svakoga svesnog nacionalnog čoveka“. ${ }^{45}$ Sa druge strane, ugušuje se i zabranjuje reč i delatnost jugoslovenskih nacionalista, kao i njihova odbrana načela i tekovina kralja Aleksandra. Dakle, stavljajući svoj potpis na Timotijevićevu interpelaciju, Desnica se svrstao u redove onih koji su istupali sa pozicija ubeđenih pristalica kraljevske diktature i njenih čvrstorukaških metoda.

43 Sačuvana je vizit kartica koja ukazuje na članstvo u ovom telu. Sasvim je izvesno da je i činjenica da je Desnica 6. septembra 1930. godine bio odlikovan Kraljevskim ordenom Jugoslovenske Krune trećeg reda stajala u vezi sa njegovim učešćem u radu pomenutog saveta. I vizit kartica i povelja o odlikovanju nalaze se u Muzej SPC, Zbirka Uroša Desnice, fascikle 1-3, fasc. 1, omot 1. O Vrhovnom zakonodavnom savetu vidi Christian Axboe NiELsen, Making Yugoslavs: Identity in King Aleksandar's Yugoslavia, Toronto 2014., 93.

44 Stenografske beleške senata Kraljevine Jugoslavije, redovan saziv za 1935 i 1936. godinu, knj. 1, od I prethodnog do XIII redovnog sastanka, od 20 oktobra 1935 do 27 marta 1936 godine sa budžetskom debatom u načelu i pojedinostima, BeIsto. 
Međutim, Desničin opozicioni stav prema Stojadinovićevoj vladi nije dugo potrajao. Kao negdašnji radikal, on se uskoro, već u decembru iste godine, našao u prilici, bolje rečeno neprilici, da bude uvučen u novi raskol u radikalskim redovima nastao u vezi sa formiranjem Jugoslovenske radikalne zajednice, nove vladine stranke pod predsedništvom premijera Stojadinovića. Ona je imala da okupi političke predstavnike većine Srba, a takvima su se smatrali radikali, Slovensku ljudsku stranku Antona Korošeca i Jugoslovensku muslimansku organizaciju Mehmeda Spahe. Poslednje dve stranke su nesumnjivo uživale podršku većine Slovenaca i bosansko-hercegovačkih muslimana. Na taj način, JRZ bi praktično uživala podršku najvećeg dela jugoslovenskog elektorata i efektivno izolovala opozicionu HSS. Ukoliko bi se postigao sporazum sa Vlatkom Mačekom, njegova stranka upotpunila bi vladavinsku kombinaciju JRZ-e. Međutim, Glavni odbor Radikalne stranke na čelu sa starim i uglednim prvakom Acom Stanojevićem je brzo postao nezadovoljan sa merom svoga uticaja u vladinoj novoj stranci, u kojoj je Stojadinović pretendovao da igra ulogu stvarnog lidera, a ne običnog opunomoćenika vođstva svoje stranke. U nastalom sukobu predsednik vlade se pokazao nadmoćniji i privukao je, zahvaljujući mogućnostima koje su stajale na raspoloženju svakoj vladi, pa i njegovoj, većinu radikala na svoju stranu. Jedan deo radikala ostao je privržen Glavnom odboru svoje stranke. Iako više nije formalno ni pripadao Radikalnoj stranci, Desničin stav bio je, s obzirom na njegov položaj i ugled, od interesa sukobljenim radikalskim frakcijama koje su očigledno računale sa njim kao sa bivšim istaknutim članom Pašićeve stranke. To nam je poznato na osnovu korespodencije između Lazara Markovića, člana Glavnog odbora koji je ponajviše bio involviran u pitanja stranačke organizacije i praktičnog rada, i Ljube Jurkovića, profesora iz Ljubljane, rodom iz Benkovca, čiji je otac Dušan bio jedan od istaknutijih radikala iz severne Dalmacije. Jurković je predlagao Markoviću da se najistaknutiji radikal iz Knina Niko Novaković privoli na priznavanje autoriteta Glavnog odbora, a ukoliko ne pristane „tada on treba da povuče konsekvencije, a Glavni odbor sa njim i njegovim prijateljima da postupi jednako kao i sa g. dr.Urošem Desnicom i protom Sergijem Urukalom “. ${ }^{46}$ On ohrabruje Markovića zapažanjem da lokalni lideri dalmatinskih Srba crpe svoj autoritet iz poverenja koje im se ukazuje iz Beograda i da oni to poverenje gube čim se ispostavi da ih beogradska centrala ne mari: „Ali Glavni odbor stranke, posle rđavog iskustva sa g.dr.Desnicom i g.dr.Novakovićem, trebaće svakako da u Dalmaciji uredi stvar organizacije stranke. “47 Svome ocu, Jurković piše da je Desnica izgubio poverenje vođstva iz Beograda „radi oportunističke („guvernamentalističke“) politike“" ${ }^{48}$ Dalje ga optužuje da misli samo na svoje lične interese. Jurković takođe ističe da je neophodno da se načelno prekine sa „sistemom poverenika sa neograničenim punomoćijem “ koji se pokazao štetnim, jer je takvim poverenicima omogućavao da sprovode neku svoju ličnu i samovoljnu politiku. Ako bi se stranačka organizacija strogo

\footnotetext{
46 AJ, Zbirka Lazara Markovića, br. 85, fascikla 2, Jurković za Markovića, 16. april 1936. Na izborima 1938. godine Ljuba Jurković je i sam promenio tabor, pa se kandidovao na zemaljskoj listi JRZ za Primorsku banovinu, u srezu Benkovac, i to kao prvi na listi. Vidi AJ, Zbirka Milana Stojadinovića, 37-49-313, Stojadinović Marku Buiću, 4. novembar 1938., skenovi 809-811.

47 AJ, Zbirka Lazara Markovića, br. 85, fascikla 2, Jurković Markoviću, 21. april 1936., Ljubljana.

48 AJ, Zbirka Lazara Markovića, br. 85, fascikla 2, Ljuba Jurković Dušanu Jurkoviću, 21. april 1936.
} 
sprovela prema svojim statutima, onda bi se teško „desilo ono što se je desilo sa gg. Desnicom, Subotićem, Urukalom i sada sa gg. Novakovićem i dr. ${ }^{\text {“49 }}$ U poslednjem sačuvanom pismu, Jurković otkriva da je senator Desnica i dalje pripadnik JNS. ${ }^{50}$ Prema Jurkoviću, dalmatinski Srbi nisu bili zadovoljni radom Desnice i drugih lokalnih srpskih prvaka pa su zato želeli da ruše njihov uticaj u javnom životu, koji je još uvek bio jak zbog pune podrške izvršne policijske vlasti. Međutim, borbu protiv Desnice poveo je i Niko Novaković, vođa JRZ-e u severnoj Dalmaciji. On upozorava da potonjega ne treba ometati u tom poslu, jer bi to značilo davanje indirektne pomoći Desnici. ${ }^{51}$ Novaković je zaista imao priličnog uspeha u svojoj agitaciji: on je formirao kninski i benkovački, a zatim i okružni odbor JRZ za Primorsku banovinu, obnovio je rad bivšeg radikalskog glasila Država, čiji je postao glavni i odgovorni urednik, a potom ostvario ubedljivu pobedu na opštinskim izborima u Kninu nad do tada vladajućim zemljoradnicima. ${ }^{52}$

Prema tome, Desnica se našao, kao i izvesni drugi narodni prvaci, u ponešto neodređenom položaju. Kao senator koji je pripadao JNS - bio je član užeg izvršnog odbora te stranke - uprkos svojoj državnoj funkciji nije bio deo vlasti u pravom smislu te reči nakon konstituisanja JRZ. On uzima učešća na skupu Pohorske akcije, koja je okupljala razne skupine oko JNS, održanom u Splitu 3. februara 1936. godine, na kome je, po zvaničnom izveštaju, učestvovalo 700-800 pristalica Budislava Grge Anđelinovića iz Dalmacije i na kome su govorili Jovo Banjanin, Petar Zec, Albert Kramer, Vasa Jovanović iz Banja Luke, Ignat Stefanović iz južne Srbije i Ivan Juriša iz Zagreba. Uz Desnicu su bila prisutna i druga dva dalmatinska senatora, Ivo Majstrović i don Frane Ivanišević, kao i narodni poslanici Ante Maštrović i Manfred Paštrović. ${ }^{33}$ Sa druge strane, oskudni podaci kojima raspolažemo o njemu sugerišu da, u periodu nakon potpisivanja interpelacije senatora Timotijevića, Desnica, u najmanju ruku, nije javno istupao protiv Stojadinovićeve vlade. Jurkovićeve opservacije o njegovom oportunističkom držanju se moraju uzeti sa izvesnom rezervom, jer potiču od političkog protivnika koji svakog radikala, makar i bivšeg, koji nije bespogovorno stao uz Glavni odbor u sukobu sa Stojadinovićem, automatski karakteriše kao vladinog poslušnika. U tom pogledu, kao korektiv Jurkovićevoj oceni može da posluži izveštaj bana Primorske banovine Josipa Jablanovića. On se mora uzeti kao merodavan pošto potiče od čoveka koji je, po prirodi svoje službene dužnosti, posmatrao stvari iz režimskog ugla, za razliku od Jurkovića, a pri tome je odlično poznavao Desnicu sa kojim je blisko sarađivao u okviru Radikalne stranke tokom 1920-ih godina, o čemu ubedljivo svedoči njihova bogata korespondencija. U odgovoru na Stojadinovićev zahtev da mu preporuči pogodnog kandidata za senatora iz svoje banovine, u cilju popunjavanja mesta upražnjenog usled smrti senatora Miće Mičića

\footnotetext{
Isto.

50 AJ, Zbirka Lazara Markovića, br. 85, fascikla 2, Jurković Markoviću, 22. maj 1936.

51 Isto.

52 Dušan Plenča, „Sjevernodalmatinska Zagora i Ravni Kotari između dva svjetska rata (1921-1941)“, drugi deo članka, Zadarska revija, 32/1983., br. 1, 63-64.

53 AJ, Zbirka Milana Stojadinovića, 37-49-313, Kraljevska banska uprava Primorske banovine Ministarstvu unutrašnjih poslova, Pov. II, Br. 3614/36, 7. mart 1936., Split, predmet: Mesečni izveštaj o političkoj situaciji, pojavama, događajima i kretanjima u masama za mesec februar 1936. god., 318-334.
} 
iz Dubrovnika, Jablanović daje pravu malu analizu političkog sveta sa svog područja. On se žali na veliku oskudicu ljudi pogodnih za javni život i rad pa nastavlja:

Desnica se otuđio, impresionista i kolebljiv. Anđelinović i njegovi prijatelji (dva-tri njih) na drugoj su strani, i, kad upravni aparat ne može više da bude u odnosu zavisnosti prema užim ciljevima njihove političke delatnosti, ne javljaju se nikako kao saradnici. Senatori su potpisnici interpelacije. U stranku JRZ stupili su od poslanika samo četiri Srbina i jedan Musliman. ${ }^{54}$

Jablanović ima reči hvale jedino za Nika Novakovića zbog njegovog uspeha u radu na organizovanju JRZ i ističe kako mu „uprav imponira solidnost i ozbiljnost političkoga rezonovanja Dr. Nika Novakovića kad ih upoređujem sa impresionističkom kolebljivosti g. Dr. Desnice i sa nedokučivom rezerviranošću Dr. [Nikole] Subotića“.55 Jablanovićev sud o Desnici nedvosmisleno pokazuje da ga on nikako nije video kao pouzdanog pristalicu vladine politike mada nije bio ni u otvoreno opozicionom stavu poput Anđelinovića. Takođe, odvaja Desnicu od Anđelinovića i njegovih prijatelja u pogledu sklonosti potonjih da iskorišćavaju državnu vlast za potrebe ostvarivanja svojih vlastitih političkih ciljeva - inače potpuno tačna optužba i karakteristično svojstvo velikog dela političke elite - što jednako demantuje tvrdnju Jurkovića o Desničinom oportunizmu i zaokupljenosti ličnim interesima.

U aprilu 1936. izvršen je atentat na poslanika Manfreda Paštrovića na koga je nepoznato lice pucalo iz revolvera kada je ovaj otvarao kapiju svoje kuće. Senator Anđelinović se žalio banu Jablanoviću da je policijska prijava povodom ovog napada sastavljena u smislu koji sugeriše da je Paštrović inscenirao čitav događaj pa je zato čak i demonstrativno otkazao zaštitu policijskog agenta dodeljenog mu radi njegove lične bezbednosti kako i sam ne bi doživeo nešto slično poput njegovog stranačkog kolege, što bi, kako je Anđelinović istakao, „bilo posvema u duhu politike gosp. Dr. Stojadinovića“. ${ }^{56}$ Ovaj ozbiljan incident bio je povod da Jablanović ukaže Desnici na nekorektnost Anđelinovićevog ponašanja i dozna od njega novosti o aktivnostima JNS:

Imao sam dug razgovor sa senatorom Dr. Desnicom i mislim da sad i on drukčije gleda na stvari, mnogo hladnije i objektivnije (...) Dr. Desnica je bez svoga pristanka uvršten od Anđelinovića u banovinski odbor JNS. Desnica je bio pozvan od Anđelinovića na sastanak JNS u Splitu, ali nije pristupio. ${ }^{57}$

I ovo svedočenje ukazuje na ambivalentnu Desničinu poziciju između režima kome nije pripadao i svoje stranke jugoslovenskih nacionalista, čiji je formalno još uvek bio član, ali od koje se postepeno udaljavao. Jablanović se, međutim, nakon kratkog vremena pokolebao u svojoj oceni političkog stava Desnice u vezi sa njegovim držanjem prilikom posete šefa JNS Petra Živkovića Splitu, kojom prilikom ga je senator dočekao: „Čudim se Desnici da je tako otvoreno ušao u ovu lažnu situaciju i u spregu sa ljudima koji su ga jednom grdili i potcenjivali. Pokušao sam nekoliko puta da Desnicu otrgnem od te sprege, ali uzalud. Koliko je De-

\footnotetext{
54 AJ, Zbirka Milana Stojadinovića, 37-49-313, Jablanović Stojadinoviću, 27. novembar 1935., $243-248$.

55 Isto.

56 AJ, Zbirka Milana Stojadinovića, 37-49-313, Jablanović Stojadinoviću, 28. april 1936., uz priloženo pismo Anđelinovića Jablanoviću, 27. april 1936., 342-346.

57 AJ, Zbirka Milana Stojadinovića, 37-49-313, Jablanović Stojadinoviću, 2. maj 1936., 347-348.
} 
snica uman, toliko je i naivan i nerealan u politici." ${ }^{\text {58 }}$ Međutim, prilikom sledeće Živkovićeve posete Splitu i Primorskoj banovini, kada je održan i stranački zbor u gradskom pozorištu i uža banovinska konferencija, dočekali su ga apotekar Niko Bonetti, predsednik mesne organizacije, i Anđelinović, koji je predsedavao zborom, ali Desnica se ne spominje u izveštaju. ${ }^{59}$

Dakle, sredinom 1936. godine, Desnica je bio u jednom veoma kompleksnom političkom položaju koji je reflektovao generalnu poziciju dalmatinskih Srba. Oni se osećaju ugroženim pred kompaktnim nacionalnim hrvatskim pokretom oličenim u Mačekovoj partiji. Sa druge strane, njihov politički front je rascepkan između različitih rivalskih srpskih partija koje se iscrpljuju u međusobnim borbama i nemaju potrebnu unutrašnju koheziju da postanu srpski ekvivalent HSS-a. Sam Desnica je, čini se, polako tonuo u političku pasivnost kada je u pitanju njegov stranački angažman u JNS mada se ponovo spominje njegov sastanak, u društvu sa Anđelinovićem i Paštrovićem, sa predsednikom stranke Živkovićem u Splitu krajem maja $1938 .{ }^{60}$ Nešto pre toga, 3. januara, prestao je njegov senatorski mandat. ${ }^{61}$ Konačno, prilikom izborne kampanje krajem te iste godine Desnica je prisustvovao izbornoj konferenciji Prvislava Grisogona, kandidata JNS na zajedničkoj opozicionoj listi čiji je nosilac bio Maček, održanoj 3. novembra u Splitu, na kojoj je bilo oko 140 lica, među kojima i Anđelinović, Ivo Majstrović i Tresić Pavičić, ali je ubrzo nakon toga, kako tvrdi zvanični izveštaj iz Primorske banovine, napustio stranku. ${ }^{62} \mathrm{~S}$ obzirom da je Desnica, kako to pokazuje njegova prethodna politička aktivnost, bio itekako veran svojim stranačkim kolegama, njegovo istupanje iz JNS mora se dovesti u vezu sa ogromnim zaokretom koji je ta stranka učinila u kampanji za izbore od 11. decembra. Iako je nominalno zadržala svoju unitarističku ideologiju nacionalnog i državnog jedinstva, njeno vođstvo na čelu sa Živkovićem je rešilo da izađe na izbore na listi Mačeka, glavnog protivnika beogradskog centralizma i zagovornika hrvatske samostalnosti, čiji sadržaj nije bio jasno definisan. Za Desnicu, vatrenog Srbina, ubeđenog Jugoslovena i protivnika HSS još iz vremena kad je njen predsednik bio pokojni Radić, uz to i čoveka kome je lični integritet bio neprikosnovena vrednost, takav neprincipijelan stav, motivisan isključivo pragmatičnom težnjom da se osigura što bolji izborni rezultat, morao je da bude neprihvatljiv. ${ }^{63}$

58 AJ, Zbirka Milana Stojadinovića, 37-49-313, Jablanović Stojadinoviću, 13. avgust 1936., 392-394.

59 AJ, Zbirka Milana Stojadinovića, 37-49-313, Jablanović Stojadinoviću, 18. maj 1937.; priložen je izveštaj Uprave policije u Splitu, Pov. br. 4144, od istog datuma, predmet: Zbor JNS u Splitu dana 17.V.1937., 501-505.

60 AJ, Zbirka Milana Stojadinovića, 37-49-313, Kraljevska banska uprava Primorske banovine, Upravno odeljenje II, Pov. II. broj 7430/38, 10. juna 1938. god. Ministarstvu unutrašnjih poslova, predmet: Mesečni izveštaj o političkoj situaciji, događajima, pojavama i pokretima za mesec maj 1938. god., 751-767.

61 Stenografske beleške Senata Kraljevine Jugoslavije, redovan saziv za 1937 i 1938 godinu, knj. 1, od prethodnog do XV redovnog sastanka, od 20 oktobra 1937 do 26 marta 1938 godine sa budžetskom debatom u načelu i pojedinostima, Beograd 1938., 13-14.

62 AJ, Zbirka Milana Stojadinovića, 37-49-313, Kraljevska banska uprava Primorske banovine, Upravno odeljenje II, Pov. II. Br. 15956/38, 21. novembar 1938., predmet: Periodični izveštaj o izbornom kretanju, Ministarstvu unutrašnjih poslova, 823-847.

63 Svoju odbojnost, pa i zgroženost, nad poratnim javnim moralom on je izrazio na sledeći upečatljiv način: „Kad bi se kome prohtjelo da kodifikuje osnove javnog, posebice političkog, morala i da postavi sankcije za njegovu povredu, kao što je krivični zakon postavio sankcije za obične zločince i prestupnike, nema sumnje, da bi se najčešća i najopasnija povreda etike nazrela u beskarakternosti, savitljivosti, beskičmenosti i servilnosti jednog ogromnog broja javnih radnika, u njihovoj lakoj adaptaciji svakoj promjeni prilika i u nagloj apostaziji od programa i načela na koja su se do tada zaklinjali, kao što nema sumnje, da bi ovo moralno dezerterstvo moglo da nađe adekvatnu sankciju samo u nepodijeljenom preziru i starih prijatelja i novih gospodara." Vidi Muzej SPC, Zbirka Uroša Desnice, fascikle 6-7; 9-10, fasc. 6, omot 4, „Osnovi političke etike“, Jugoslovenske novine (Zagreb), br. 59, 18 novembra 1937. 


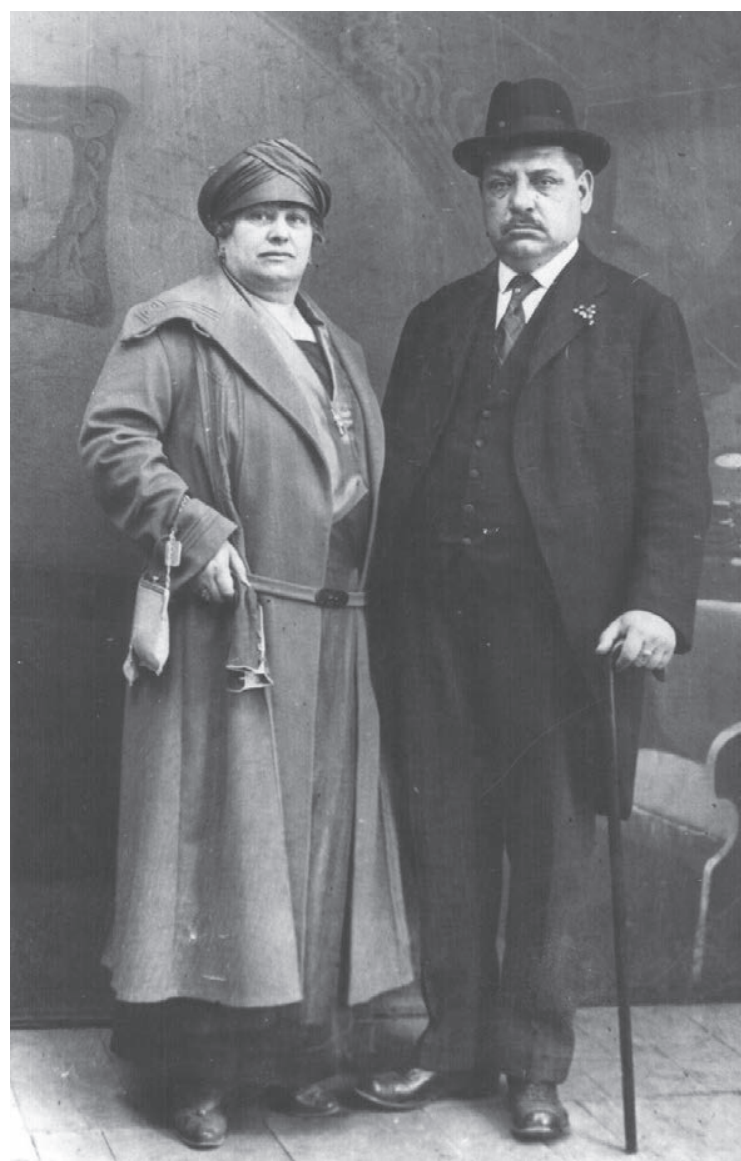

Sl. 2. Uroš Desnica sa suprugom Fani
Iako više nije bio državni zvaničnik, pa ni stranački aktivan, Desnica je i dalje zabrinuto pratio društvene i političke procese u Jugoslaviji, ponajviše razvoj hrvatskog pitanja. U neštampanom novinskom članku, koji očigledno nije predan čitalačkoj publici pod paskom cenzure ili autocenzure, Desnica još jednom razmatra prirodu tog pitanja i načine njegovog rešavanja te nalazi da je sporazum koji bi, po definiciji, podrazumevao popuštanje sa obe strane nemoguć s obzirom na dogmatsku nefleksibilnost hrvatskog pokreta:

Zato se od vodstva hrvatskog pokreta i ne iznose zahtjevi u detalju, jer to vodstvo, inače sasvim logično, misli, da se detalji sami po sebi izvode iz njihovih načelnih zasada: Hrvati, poseban narod, različan od srpskog i donekle oprečan od srpskog; pravo svakog naroda, pa i hrvatskoga, na svoju potpunu slobodu i na svoju posebnu državnost a pravo svake države da po svojoj slobodnoj volji stupi s drugom državom u složenu državnu zajednicu što, prirodno, sadrži i pravo, da u tu zajednicu ne stupi ili, ako je već stupila, da je otkaže. ${ }^{64}$

S obzirom na jasne implikacije ovih temeljnih pretpostavki, Desnica smatra „da bi sporazum na ovakim osnovama mogao da se zaključi još samo u Brest-Litovskom [aluzija na mir zaključen između Nemačke i Sovjetske Rusije u martu 1918. godine pod izuzetno teškim uslovima za potonju zemlju]“ ${ }^{65} \mathrm{U}$ takvim uslovima, preostaje samo jedno rešenje - „zakon i vrijeme“. Prema tome, Desnica drži da je hrvatsko pitanje i dostiglo razmere jednog masovnog, stihijski snažnog i ultimativnog pokreta usled slabosti državne administracije da uspostavi „krutu, bespoštednu legalitarnost“ i veruje da bi vaspostavljanje punog zakonskog poretka, pa samim tim i vere u zakon i strah od zakona među širokom narodnim masama, doveli do toga da hrvatski problem postane „za dvije trećine bespredmetan“, dok bi ono što od njega preostane moglo „da se zavješta budućem pokoljenju, koje - ako znaci ne varaju - čekaju nove, krupnije brige i iskušenja“. ${ }^{66}$

\footnotetext{
${ }_{64}$ Muzej SPC, Zbirka Uroša Desnice, fascikle 6-7; 9-10, fasc. 6, omot 4, „Glose o 'hrvatskom pitanju'“ (neštampani tekst iz 1939. godine). 
U avgustu 1939. godine dolazi do formiranja Banovine Hrvatske, što je preobrazilo unutrašnju politiku i uređenje u Kraljevini stvaranjem faktički federalne hrvatske jedinice dok je ostatak zemlje zadržao pređašnju administrativnu podelu. Ovaj proces federalizacije Jugoslavije neće nikada ni biti okončan usled ulaska zemlje u vrtlog Drugog svetskog rata. Za brojne Srbe koji su se našli na teritoriji novoosnovane Banovine takva nagla i duboka promena izazvala je konfuziju, zabrinutost, pa i strah od toga kakav će biti njihov položaj u ovim novim uslovima. Uprkos fundamentalnom unutrašnjem preobražaju zemlje, Desnica je ostao veran izvornoj jugoslovenskoj ideji pa je svoje stavove povremeno objavljivao na stranicama novog i nedugovečnog splitskog Narodnog lista, glasila malobrojnih i marginalizovanih jugoslovenskih nacionalista. Neposredno nakon objavljivanja sporazuma između predsednika vlade Cvetkovića i Mačeka, kada je još bilo nejasno kako će on izgledati u praksi, Desnica razmatra istoriju borbe za ujedinjenje južnih Slovena i njihovo dvadesetogodišnje iskustvo života u zajedničkoj državi. Dok je prvi period do 1918. godine bio „epos“, nakon toga usledila je

(...) epoha lutanja i griješenja, epoha kojom ne možemo da se ponesemo, epoha obilježena voljnim i nevoljnim pregrešenjima i zabludama, epoha strastvenosti, međusobne borbe i razjedinjavanja, u kojoj samo po slijepoj sreći nije nastradala država, kao politička jedinka, ali je nastradalo naše duhovno jedinstvo, naš politički i društveni moral i svijest o našoj nacionalnoj identičnosti. ${ }^{67}$

Desnica konstatuje da bi bilo teško utvrditi objektivno na kome leži krivica za takvo stanje, ali, što je još važnije, od toga ne bi bilo nikakve praktične koristi: „Mi moramo da se naoružamo smjelošću pa da resignacijom primimo svoju sudbu i spoznamo stanje u koje smo dospjeli i - ako već nije dockan - da se postaramo za lijek." U tom smislu, sporazum Cvetković - Maček može da bude dobrodošao ukoliko, bez obzira na njegov sadržaj ili način na koji je donesen, ugovorne strane imaju zajednički konačni cilj i drže se lojalno. Desnica je rezervisan u oceni sporazuma, jer „po načinu kako se bude primjenjivao i po svom psihološkom dejstvu na šire narodne krugove i hrvatskog i srpskog imena, može za ovu državu i njen narod da zabruja kao pobjedna pjesma ili da zabreca, kao pogrebno zvono“.68

Nešto kasnije, Desnica se odaziva pozivu uredništva Narodnog lista da iznese svoj stav povodom obrazovanja jedinstvenog srpskog fronta u Banovini Hrvatskoj. On nastajanje tog pokreta vidi kao prirodnu reakciju na prekompoziciju državnog uređenja na potpuno drugačijim principima, što je podrazumevalo da se načelo narodnog jedinstva zameni konceptom o tri različita naroda i konceptom o suverenosti i državnosti hrvatskog naroda u svojoj banovini, ,jer je tada logično, da drugi narod ne može da bude saučesnik u tom suverenitetu već da mora pasti na podređeni stepen narodne manjine“. ${ }^{69}$ Politička homogenizacija Srba u Banovini Hrvatskoj, Desnica je tvrdio, isto je toliko psihološki opravdana

67 „Osvrt na prošlost - pouka za budućnost“, Narodni list (Split), br. 1, 1. 11. 1939., 4. Dugujem veliku zahvalnost kolegi Marijanu Buljanu, koji je bio toliko ljubazan da mi dostavi kopiju ovoga i sledeća dva citirana novinska članka.

68 Isto.

69 „O srpskom frontu (pismo iz sjeverne Dalmacije)“, Narodni list (Split), br. 4, 23. 11. 1939., 4. Članak je potpisan sa „Nestor ljetopisac“. 
koliko i pojava hrvatskog pokreta. Međutim, potpuno je drugo pitanje da li će srpski pokret imati isto toliko uspeha u svojoj političkoj akciji kao što je to bio slučaj sa hrvatskim, odnosno da li će Srbi uspeti da ostvare nekakvu svoju autonomiju u okviru hrvatske banovine. Desnica ukazuje da, ako bi se demokratsko načelo o samoodređenju naroda izvelo do krajnjih konsekvenci, onda bi se, s obzirom na veliku izmešanost Srba i Hrvata, stvorio jedan sistem koncentričnih krugova „u kom bi svaki krug pretstavljao jednu nacionalnu samostalnost u krilu druge, veće nacionalne samostalnosti, tako da bi najveći krug pretstavljao Jugoslaviju a najmanji krug obor župske crkve u Kaštel Štafiliću“. Ideja o srpskom frontu je otuda zasnovana na neumoljivoj logici, ali su realni uslovi u kojima je ovaj pokret delovao bili sasvim drugačiji od onih u kojima je hrvatski pokret ostvario uspeh. Postojale su dve ključne razlike. Srpski pokret nije imao vođu sa neospornim i apsolutnim autoritetom kao što je to bio Maček kod Hrvata. Pored toga, čak ni masa srpskog stanovništva nije više bila homogena. Desnica to pokazuje na primeru severne Dalmacije, u kojoj je glavnina Srba, po zanimanju „stočara i sebara“, grupisana na prostoru između Zrmanje i Cetine i po obroncima Velebita i Dinare dok su se pojedini otisnuli u obližnje varoši „za sitnom trgovinom i sitnim posjedom“ formirajući tako srednji stalež koji je u austrijska vremena „bio gotovo jedini nosilac nacionalne svijesti u Dalmaciji i unio neokaljanu tu svijest u novu državu“. Međutim, u novijim vremenima nestalo je harmonije između seoskog stanovništva i gradskog staleža:

U nadraženoj klasnoj svijesti jednih i umrtvljenoj nacionalnoj svijesti drugih njihovi su se putevi razišli. Zaćutala je pjesma o Marku i Milošu, izblijedili su likovi Kosovke djevojke i majke Jevrosime, glad i malarija još uvijek drže svoj plijen a ekonomska propast potražila je i "plemstvo“ u njegovu dućanu i njegovu parlogu. Zacarila se je apatija i mrzovolja a na nebosklonu stali su da svjetlucaju u još nejasnim ali dobro uočljivim obrisima utvare Lenjina i Staljina. ${ }^{70}$

Desnica zaključuje da ovo nije „vojska da se pođe na Kosovo“ i da bi srpski front bio i suvišan „kod postojanja jugoslavenskog fronta, koji pruža puni ekvivalent i za srpski front i za hrvatski pokret, a, možda, i nešto mnogo više od jednog i od drugog" ${ }^{71}$

Iako je Jugoslavija već više od pola godine uspešno održavala svoju neutralnost u novom ratnom požaru koji je zahvatio Evropu, Desnica je u još jednom autorskom članku razmatrao opasnosti koje malim zemljama, pa i njegovoj, prete i od zaključivanja mira. Polazeći od činjenice da je nemoguće predvideti na osnovu kojih principa i kriterijuma će se oblikovati posleratna mapa Evrope, on ističe da se poslednje i najjače otporno sredstvo za male narode, koji lako mogu da postanu moneta za potkusurivanje velikih sila, sastoji u njihovoj vlastitoj vitalnosti, nacionalnoj koheziji, moralnoj snazi i odlučnosti da se brane. Kao primer navodi mirovnu konferenciju posle Prvog svetskog rata na kojoj su Jugosloveni ostvarili svoje ambicije zahvaljujući velikom kapitalu koji su predstavljali herojska borba Srbije i jednodušni samopregorni napori prečanskih Jugoslovena da dokažu narodno jedinstvo i 
opravdanost potrebe za stvaranjem jugoslovenske države. Ali za razliku od 1919. godine, novo „ročište naroda“ zateći će Jugoslovene u mnogo drugačijem stanju: oni ne samo da neće imati preimućstva koja proističu iz pripadništva pobedničkoj strani, već je i unutrašnja situacija u zemlji u opreci sa onom kakva je bila pre 20 godina:

Mi smo se zvanično odrekli narodnog jedinstva i stali na sklisko tlo triju narodnih individualiteta i mi u svakoj, pa i najsitnijoj manifestaciji dnevnog života osjećamo potrebu da naglasimo i podvučemo ovu novu vjeru. Kod nas se prave, nekom sadističkom nasladom, svi napori za što potpunije odvajanje u svim oblastima javnog, društvenog i kulturnog života (...) Ističe se i zahtjev za stvaranjem novog hrvatskog književnog jezika, koji bi zamijenio štokavsko narječje, onu, još u Starčevićevim zemanima anatemisanu ,govedarštinu“. Predlaže se obustava izdavanja Akademijina rječnika hrvatskog ili srpskog jezika i pokretanje novog, samo hrvatskog, rječnika i, kao kruna ove trke za posebnim narodnim individualitetom, postavlja se naučna teorija koja odriče Hrvatima slavensko poreklo te im rivendicira etničko naslijeđe od Gota. ${ }^{72}$

Svoje poglede na srpsko-hrvatski spor Desnica obrazlaže i u pismu upućenom Dragoslavu Stranjakoviću u januaru 1941. godine nastalom kao odgovor na poziv pripadnika Srpskog kulturnog kluba uglednim javnim ličnostima da iznesu svoj odgovor na pitanje šta da se radi u teškoj situaciji u kojoj se zemlja nalazila. Uz značajnu napomenu da se podvrgao „najstrožijoj autocenzuri a ko poznaje prilike priznaće da jedan Srbin u Banovini Hrvatskoj ne može da bude obazriviji i dotjeraniji“", Desnica piše jednu malu i lucidnu studiju o istorijatu srpskohrvatskih odnosa, da bi na kraju izneo svoj sud: „Odgovor može da da samo kolektiv, srpski, hrvatski i slovenački kolektiv kojemu treba stvoriti uslove za slobodan pismen i usmen izraz svog mišljenja. (...) i samo tako moći će da se izbjegne docnijem osporavanju i ponovnom traženju 'restitutio in integrum.'“ Ovaj odgovor je u do sada jedinoj analizi protumačen kao, sa jedne strane, implicitna kritika Srpskog kulturnog kluba čiji mnogi članovi su usled svog prethodnog delovanja i sami nosili deo odgovornosti za teške prilike, a, sa druge strane, kao Desničino zalaganje za uvažavanje demokratski izražene volje Hrvata i Slovenaca te za njegovo vraćanje svojim političkim počecima „novog kursa“ oličenog u Zadarskoj rezoluciji. ${ }^{73}$ Privlačno i pomalo romantično kako ovo tumačenje deluje, ono svakako nije jedino moguće, a možda ni najuverljivije. Obraćajući se sa senatske govornice, Desnica je svojevremeno jasno stavio do znanja, citirajući latinske sentence, kako je on to kao pravnik i veoma obrazovan čovek inače često činio, da je spas države vrhovni zakon i preteže nad obzirima prava i pravde. ${ }^{74}$ To samo po sebi nikako ne znači da je bio nedemokrata, ali ukazuje da demokratsko načelo nije bilo glavni postulat na osnovu koga se on određivao prema problemu državnog uređenja. Čak i ako se ostavi postrani njegova napomena o autocenzuri koju je primenio prilikom formulisanja svog odgovora, Desnica je, kao objektivni pravnik i pronicljivi posmatrač društvenih događaja, morao da bude svestan u januaru 1940. da je demokratsko izražavanje volje naroda u Jugoslaviji u kojoj je raspuštena Narodna skupština nakon postizanja sporazuma o

„Razmišljanja“, Narodni list (Split), br. 15, 18. 4. 1940., 2.

73 D. Roksandić, „Zatvaranje kruga“, 301-302; čitav tekst Desničinog odgovora objavljen je kao prilog na kraju ovog eseja (309-313).

74 Stenografske beleške senata Kraljevine Jugoslavije, XXXIII redovni sastanak, 29. mart 1933., 182. 
Banovini Hrvatskoj, a bez sazivanja novih parlamentarnih izbora, i s obzirom na ratno okruženje u Evropi teško ostvariva i malo izgledna mogućnost, bar u doglednoj budućnosti. Sa druge strane, Desnica je savršeno dobro shvatao da je za validnost i trajnost svakog sporazuma neophodan puni legitimitet onih koji taj sporazum zaključuju u ime naroda. Kako steći taj legitimitet u postojećim uslovima, pre svega kada je u pitanju srpska strana - nije se dovodilo u pitanje da Maček zaista predstavlja većinu Hrvata - to Desnica nije objasnio. Kao i toliki drugi, ni on nije znao kako da rasplete Gordijev čvor srpsko-hrvatskih odnosa pa je završio rečima: „Za uspjeh ovog pokušaja, razumije se, niko ne može da preuzme jamstvo ali niko neće moći da se otme istorijskoj odgovornosti ako taj pokušaj ne preduzme (...) jer svakome mora da se nametne uvjerenje, da je on, poslije tolikih bezuspješnih pokušaja, još ultima ratio.“75

Poslednja i kratkotrajna epizoda iz Desničinog života tiče se njegovog političkog angažmana nakon raspada Kraljevine u katastrofalnom Aprilskom ratu i obrazovanja Pavelićeve Nezavisne Države Hrvatske, koja je svojim granicama obuhvatala ogromnu većinu prečanskih Srba. Najveći deo Dalmacije je sačinjavao deo teritorije koju je Pavelić morao da ustupi Italiji, svojoj zaštitnici zahvaljujući kojoj je i bio u mogućnosti da preuzme vlast u Hrvatskoj i saveznici u okviru osovinske koalicije. Uskoro su italijanska okupacija i neprekidno natezanje oko razgraničenja između NDH i italijanske zone postali izvor stalnih napetosti između nominalnih saveznika, Rima i Zagreba. Srbi u Dalmaciji našli su se pod vlašću Italijana $\mathrm{i}$ to ih je spasilo od tragične sudbine njihovih sunarodnika na teritoriji NDH koji su, kao rasno nepoželjni element, bili izloženi ustaškom genocidu. Pored toga, Italijani su stekli velike simpatije Srba, jer su u brojnim prilikama sprečavali ustaške zločine, spašavali srpske civile od sigurne i monstruozne smrti, primali i zbrinjavali izbeglice, pa čak i istraživali počinjene zločine pronalazeći i otkopavajući leševe. Nakon početnog šoka izazvanog razmerama i žestinom ustaškog terora, srpski ustanici u Lici, Kordunu, Bosanskoj krajini, severnoj Dalmaciji i istočnoj Hercegovini zbrisali su ustašku vlast u tim krajevima tokom juna i jula 1941. godine. U takvim uslovima dolazi do kontakta između italijanskih vlasti i istaknutih srpskih ličnosti iz severne Dalmacije: u Kninu se u maju sastaje civilni komesar Athos Bartollucci sa Nikom Novakovićem i Boškom Desnicom, a 23. jula u Benkovcu je održan sastanak na kome je prisustvovao veći broj srpskih prvaka. U ovom ranom periodu rata, do saradnje između Srba i italijanske okupacione vlasti dolazi na osnovu jasnog zajedničkog interesa: prvima je saradnja sa Italijanima, pa i proširivanje njihove vlasti na što veći deo područja naseljenih Srbima, jedini način da se sačuvaju od biološkog uništavanja dok Italijani uviđaju da im srpsko stanovništvo može korisno poslužiti kao oslonac u njihovoj vlastitoj politici koja je išla za tim da proširi italijansku anektiranu zonu na račun $\mathrm{NDH}$, pre svega onih područja naseljenih srpskim življem. ${ }^{76}$ Pri tome, srpski otpor ustaškom režimu, izazvan borbom za opstanak, lišen je u ovoj fazi bilo kakve ideološke forme. Bivši aktivni oficir Vojske Kraljevine Jugoslavije Stevan Ćuruvija je to jednostavno izrazio rečima: „Cilj ustanka je odbrana od ustaškog klanja i obaranje ustaškog režima po mogućnosti.“"77 Tek

\footnotetext{
75 D. Roksandić, „Zatvaranje kruga“, 313.

76 Za detaljnu analizu vidi Kosta Nikolıć, Italijanska vojska i četnici u Drugom svetskom ratu u Jugoslaviji 1941-1943., Beograd 2008., poglavlja I i II.

77 Citirano u D. Plenča, Kninska ratna vremena, 212, fusnota 198.
} 
kasnije će doći do jasne diferencijacije u isprva jedinstvenom pokretu otpora na komunistepartizane i rojalističke četnike. Otuda su sasvim neodržive ocene iz dela jugoslovenske istoriografije socijalističkog perioda, utemeljene na ideološkim klišeima, koje sve srpske prvake bez razlike, uključujući i samog Uroša Desnicu, diskvalifikuju odrednicom „velikosrpskih političara" od samog početka rata. ${ }^{78}$ Prevashodni cilj ovoga postupka bio je da se grubim prećutkivanjem jednih i prenaglašavanjem, kao i krivotvorenjem, drugih činjenica stvori slika, koja suštinski nije odgovarala realnosti prvih ustaničkih meseci, o jedinoj i isključivoj ulozi Komunističke partije Jugoslavije u organizovanju oružanog otpora neprijatelju, „stranom i domaćem“, pri čemu su svi ostali „građanski“ pojedinci i grupe stigmatizovani kao domaći izdajnici i sluge okupatora bez ikakve ozbiljne analize okolnosti u kojima su delovali. Desničin primer je naročito ilustrativan u ovom pogledu, jer ga autor obimne studije o Kninskoj krajini, zaslepljen svojim ideološkim predrasudama, navodi kao učesnika pomenutog sastanka italijanskih zvaničnika i uglednih Srba u Benkovcu 23. jula 1941. iako je Desnica, teško bolestan još od leta 1938. godine, preminuo deset dana pre toga skupa. ${ }^{79}$ Biograf Vladana Desnice navodi da je Uroš vreme od ulaska Italijana u Split pa do svoje smrti proveo u kućnom pritvoru nametnutom od strane okupacijskih vlasti. ${ }^{80} \mathrm{~S}$ obzirom na kritično zdravstveno stanje i datum smrti, Desnica nikako i nije mogao da odigra neku značajniju političku ulogu u okupiranom Splitu i Dalmaciji.

Njegova tragedija bila je tipična za čitavu jednu generaciju: odrasli u vreme koje je donelo evoluciju od zaoštrenosti srpsko-hrvatskih odnosa pod austrijskom vlašću do postepenog približavanja i političke saradnje te konačno i ostvarenja do skoro nezamislivog sna o jedinstvenoj i nezavisnoj državi Jugoslovena, Desnica i njegovi vršnjaci doživeli su ostvarenje najsmelijih ambicija, a zatim posmatrali kako je stvarnost jugoslovenske države ubrzo opet otvorila ona pitanja i rane za koja su oni mislili da će zauvek ostati u prošlosti, da bi potom bili i svedoci strahota tokom Drugog svetskog rata. Smrt je ipak došla suviše kasno za Desnicu da bi ga poštedela od bolne spoznaje da su srpsko-hrvatski odnosi ušli u naročito dramatičnu fazu krvavog građanskog rata u uslovima strane okupacije i postojanja kvislinške tvorevine NDH što je svakako moralo da izazove izuzetno mučan utisak, teško razočarenje i ogorčenje u duši čoveka koji je bio i ostao veliki srpski patriota, ali i iskreni pobornik jugoslovenskog jedinstva i zatočnik ideje da su Srbi i Hrvati, kao i Slovenci, jedan narod.

\footnotetext{
78 Isto, 209; Đuro StanisavlJEvić, „Pojava i razvitak četničkog pokreta u Hrvatskoj 1941-1942. godine“, Istorija XX veka: zbornik radova, knj. IV, Beograd 1962., 18-19.

79 D. PlenčA, Kninska ratna vremena, 209. Dve umrlice, jedna dvojezična, na italijanskom i srpsko-hrvatskom jeziku latiničnim pismom, i druga na srpsko-hrvatskom napisana ćirilicom, navode kao datum smrti 13. jul 1941. godine. Vidi u Muzej SPC, Zbirka Uroša Desnice, fascikle 1-3, fasc. 1, omot 4.

80 Dušan Marinković, „Biografija Vladana Desnice“, Hotimično iskustvo: diskurzivna proza Vladana Desnice. Knjiga druga (prir. Dušan Marinković), Zagreb 2006., 219.
} 


\section{$\cos$}

\section{Notes towards a Biography: The Political Career of Uroš Desnica During Trying Times (i9I9-I94I)}

This essay is an attempt towards reconstructing the political career of Uroš Desnica between the world wars, based on all accessible archival materials and writings. A member of a renowned family, Desnica was one of the most eminent political figures amons Serbs in northern Dalmatia even before the First World War. Special attention has been given to his views on Serbo-Croatian relations and the Yugoslav idea, as well as towards an analysis of his work in People's Radical Party led by Nikola Pašić and the Yugoslav National Party during the January 6th dictatorship and in later times. Alongside this, consideration has been given to his work in political posts, first as vice president of the Dalmatian regional government, and later as a member of parliament and senator. Desnica was a great Serbian patriot, who truly believed that Serbs, Croats and Slovenes were one nation, and that the Kingdom of Serbs, Croats and Slovenes was a natural and appropriate embodiment of the Yugoslav idea, giving the best guarantees for an undisturbed cultural development of its people and security from foreign foes. During the 1920s he was an avid opponent of Croatian Peasant Party led by Stjepan Radić, even during the times when it was in coalition with his own Radicals, as he found it to be Serbophobic and disobedient towards the state. However, he never slid down the path towards chauvinism. He accepted and supported the personal regime of King Alexander, even took part in it as a senator, because of his deeply held beliefs that it had been unavoidable in the midst of a serious crisis enveloping Yugoslavia, and that the concept of integral Yugoslavdom was correct for the country. Uroš Desnica proved the sincerity of his Yugoslav beliefs by remaining faithful to them, as well as to the Yugoslav National Party which propagated them, after the death of King Alexander when "tribal parties" recovered their voices, even after the founding of the Croatian Banovina which formally signified the fact that the formula of three particular peope and Croatian sovereignty gained a foothold in territorial autonomy.

Keywords: Uroš Desnica, northern Dalmatia, Serbs, Croats, Yugoslavia, People’s Radical Party

\section{$\cos$}

\section{Arhivski fondovi}

Arhiv Jugoslavije, Beograd

AJ-138, Ministarski savet Kraljevine Jugoslavije

AJ-85, Zbirka Lazara Markovića

AJ-37, Zbirka Milana Stojadinovića

Muzej Srpske pravoslavne crkve, Beograd, Fundus dvora Jankovića, Zbirka Dr Uroša Desnice (1874-1941) 


\section{Literatura i publikovani izvori}

Nielsen Christian AxвоE, Making Yugoslavs: Identity in King Aleksandar's Yugoslavia, Toronto 2014.

Sofija Božıć, „Između demokrata i radikala: produbljivanje političkih podela među Srbima u $\mathrm{Hr}$ vatskoj i parlamentarni izbori 1923“, Istorija 20. veka, 25/2007., br. 2, 37-58.

Sofija BožIĆ, Srbi u Hrvatskoj 1918-1929., Beograd 2008.

Vladan Jovanović, „Članovi porodice Desnica u jugoslovenskim enciklopedijama i leksikonima“, Dijalog povijesničara - istoričara, knj. 9 (ur. Hans-Georg Fleck i Igor Graovac), Zagreb 2005., 243-257.

Dušan Marinković, „Biografija Vladana Desnice“, Hotimično iskustvo: diskurzivna proza Vladana Desnice. Knjiga druga (prir. Dušan Marinković), Zagreb 2006., 217-250.

Kosta Nikolić, Italijanska vojska i četnici u Drugom svetskom ratu u Jugoslaviji 1941-1943., Beograd 2008.

Narodni list (Split) 1939. - 1940.

Dušan PlenčA, Kninska ratna vremena 1850-1946: Knin, Drniš, Bukovica, Ravni Kotari, Zagreb 1986.

Dušan PlenčA, „Sjevernodalmatinska Zagora i Ravni Kotari između dva svjetska rata (19211941)“, Zadarska revija, 32/1983., br. 1, 58-72.

Drago Roksandić, „Dr. Uroš Desnica 1918. - 1921.: životopisne nedoumice na raskrižju epoha“, Spalatumque dedit ortum: zbornik povodom desete godišnjice Odsjeka za povijest Filozofskog fakulteta u Splitu (ur. Ivan Basić i Marko Rimac), Split 2014., 499-511.

Drago Roksandić, „Zatvaranje kruga. Dr Uroš Desnica (Obrovac, 28. VIII 1874 - Split, 13. VII 1941)“, Spomenica dr Danice Milić (ur. Bojana Miljković-Katić), Beograd 2014., 295-313.

Milorad Savić (ur.), Baština dvora Jankovića, Beograd 2006.

Đuro STANiSAVlJEvić, „Pojava i razvitak četničkog pokreta u Hrvatskoj 1941-1942. godine“, Istorija XX veka: zbornik radova, knj. IV, Beograd 1962., 5-140.

Stenografske beleške Narodne skupštine Kraljevine Srba, Hrvata i Slovenaca, Pregled o radu Narodne Skupštine Kraljevine Srba, Hrvata i Slovenaca za skupštinsku periodu od 16. aprila 1923. do 10. novembra 1924., Beograd 1928.

Stenografske beleške Senata Kraljevine Jugoslavije, Prvi prethodni sastanak Senata, br. 1, sastanak održan 11. januara 1932., Beograd 1932.

Stenografske beleške senata Kraljevine Jugoslavije, knj. II, od XVIII do XL redovnog sastanka od 22 marta do 19 oktobra 1932, Beograd 1932.

Stenografske beleške senata Kraljevine Jugoslavije, XXXIII redovni sastanak, držan 29. mart 1933., Beograd 1933.

Stenografske beleške senata Kraljevine Jugoslavije, redovan saziv za 1935 i 1936. godinu, knj. 1, od I prethodnog do XIII redovnog sastanka, od 20 oktobra 1935 do 27 marta 1936 godine sa budžetskom debatom u načelu i pojedinostima, Beograd 1936.

Stenografske beleške Senata Kraljevine Jugoslavije, redovan saziv za 1937 i 1938 godinu, knj. 1, od prethodnog do XV redovnog sastanka, od 20 oktobra 1937 do 26 marta 1938 godine sa budžetskom debatom u načelu i pojedinostima, Beograd 1938.

Filip Škiljan, Znameniti Srbi u Hrvatskoj, Zagreb 2009.

Čedomir VIŠNuIĆ, Srbi u Hrvatskoj 1918-1941: anotirana bibliografija, Zagreb 2000. 